\title{
Investigation of corrosion pattern of AISI 316 and AISI 304 stainless steels in $\mathrm{Na}_{2} \mathrm{~B}_{4} \mathrm{O}_{7} \cdot 5 \mathrm{H}_{2} \mathrm{O}$ solution
}

\author{
M. Akgul, ${ }^{1}$ H. Gerengi, ${ }^{2} *$ O. Camlibel ${ }^{3}$ and M. Sahin ${ }^{4}$ \\ ${ }^{1}$ Department of Materials and Metallurgical Engineering, Seydişehir A. Cengiz Faculty \\ of Engineering, Necmettin Erbakan University, 42370 Konya, Turkey \\ ${ }^{2}$ Corrosion Research Laboratory, Department of Mechanical Engineering, Faculty \\ of Engineering, Duzce University, 81620 Duzce, Turkey \\ ${ }^{3}$ Department of Materials and Materials Processing Technology, Kırlkkale University, \\ Kırıkale Vocational School, 71450 Kırıkkale, Turkey \\ ${ }^{4}$ Department of Energy System Engineering, Faculty of Engineering and Natural Sciences, \\ Yıldırım Beyazıt University, 06010 Ankara, Turkey \\ *E-mail: corros.res.lab@gmail.com
}

\begin{abstract}
The corrosion behaviour of AISI 316 and AISI 304 stainless steels in $\mathrm{Na}_{2} \mathrm{~B}_{4} \mathrm{O}_{7} \cdot 5 \mathrm{H}_{2} \mathrm{O}$ solutions with various concentrations $(3 \%, 6 \%$ and $9 \% \mathrm{w} / \mathrm{w})$ commonly used in wood industry was investigated by using electrochemical impedance spectroscopy and polarisation techniques. The results reveal that the dissolution pattern of the studied steel samples is in the order $3 \%>6 \%>9 \%$. The AISI 316 stainless steel is found to exhibit better corrosion resistance than the 304-type stainless steel alloy.
\end{abstract}

Keywords: AISI 316; $\mathrm{AISI} 304$; corrosion; $\mathrm{Na}_{2} \mathrm{~B}_{4} \mathrm{O}_{7} \cdot 5 \mathrm{H}_{2} \mathrm{O}$.

Received: January 18, 2017. Published: February 14, 2017.

doi: $\underline{10.17675 / 2305-6894-2017-6-1-6}$

\section{Introduction}

Corrosion can be defined as the deterioration of a material's properties due to interaction with its environment [1]. Metal corrosion is predominantly an electrochemical process that cannot be stopped; it can, however, be slowed, for example, through the use of corrosion inhibitors, cathodic protection techniques, or through the application of paint systems containing corrosion inhibitors [2].

There are many industrial systems and commercial applications available that act as inhibitors, including cooling systems, refinery units, pipelines, chemicals, oil and gas production units, boilers and water processing equipment, paints, pigments, lubricants, etc. [3]. Corrosion inhibitors have been classified in many ways, but one of the most common is to divide them into organic and inorganic inhibitors.

Organic inhibitors build up a protective hydrophobic film of adsorbed molecules on the metal surface which provides a barrier to the dissolution of the metal in the electrolyte 
$[4,5]$. These inhibitors must be soluble or dispersible in the medium surrounding the metal [6]. Moreover, organic corrosion inhibitors usually contain polar functions with nitrogen, oxygen and/or sulphur in a conjugated system. At the first stage, the inhibiting action is attributed to the adsorption of the additives into the metal/solution interface $[7,8]$.

The use of inorganic inhibitors as an alternative to organic compounds is based on the possible degradation of organic compounds with time and temperature. Inorganic corrosion inhibitors are generally accepted as being efficient and capable of passivating metals by forming a monoatomic or polyatomic oxide film at the electrode surface.

The safety and environmental issues arising with the industrial use of corrosion inhibitors have recently become a global concern. Due to increasing environmental awareness and the adverse effects of some chemicals, current research activities have been geared towards developing cheap, non-toxic and environmentally friendly corrosion inhibitors [10-13].

Borates are inorganic salts of boron formed by combining with oxygen and other elements. In nature, boron is found in the form of boric acid or borate salts. Boric acid, borax, borax hydrates and sodium perborates are all commercially important boron compounds [14]. They are used in a wide range of applications in agriculture as well as in detergents, wood treatments, fibreglass, glass and ceramics. Borates act as a flux and an inorganic binder in tile bodies, increasing the dry mechanical strength and reducing the firing temperature, both of which result in energy savings [15]. Borax pentahydrate has been incorporated in many aqueous systems. It protects ferrous metals against oxidation and is used in the manufacture of automotive anti-freeze formulations, water treatment chemicals, and metal-working fluids [16, 17]. However, Baker [18] had noted that borates can be corrosive to metals in humid or moist environments. Zhang [19] and Williams [20] pointed out that borates should be used in dry environments, because of their vulnerability to leaching. On this backdrop, this study was designed to examine the influence of $\mathrm{Na}_{2} \mathrm{~B}_{4} \mathrm{O}_{7} \cdot 5 \mathrm{H}_{2} \mathrm{O}$ solution on the corrosion behaviour of AISI 316 and AISI 304 stainless steel alloys. The commonly used concentration of this compound in the wood industry is $3 \%, 6 \%$ and $9 \%$ (w/w, unless otherwise indicated), hence we employed these concentrations in our investigation. Electrochemical impedance spectroscopy (EIS) and polarisation resistance methods were utilized to investigate the corrosion mechanism.

\section{Experimental Approach}

\subsection{Materials}

The substrates used in this study were AISI 316 and AISI 304 stainless steels. Prior to immersion testing, each sample $\left(0.2 \mathrm{~cm}^{2}\right.$ in size $)$ was first prepared with $400-1800$ emery paper, cleaned with distilled water, degreased with acetone, and then dried. Table 1 shows the composition (wt.\%) of the metals used in the study. 
Table 1. Composition of metals used in the study (wt. \%).

\begin{tabular}{cccccccccccc}
\hline Metals & $\mathbf{C}$ & $\mathbf{M n}$ & $\mathbf{S i}$ & $\mathbf{S}$ & $\mathbf{P}$ & $\mathbf{C r}$ & $\mathbf{N i}$ & $\mathbf{C u}$ & $\mathbf{M o}$ & $\mathbf{C o}$ & $\mathbf{F e}$ \\
\hline AISI 304 & 0.032 & 1.53 & 0.43 & 0.025 & 0.035 & 18.17 & 8.07 & 0.66 & 0.27 & 0.14 & 69.46 \\
\hline AISI 316 & 0.021 & 1.26 & 0.44 & 0.026 & 0.035 & 16.29 & 10.10 & 0.60 & 2.10 & 0.22 & 68.85 \\
\hline
\end{tabular}

The $\mathrm{Na}_{2} \mathrm{~B}_{4} \mathrm{O}_{7} \cdot 5 \mathrm{H}_{2} \mathrm{O}$ was easily dissolved in distilled water at $60^{\circ} \mathrm{C}$. In order to stabilise the samples, they were immersed in a corrosion cell for $60 \mathrm{~min}$ before each measurement. Concentrations of $\mathrm{Na}_{2} \mathrm{~B}_{4} \mathrm{O}_{7} \cdot 5 \mathrm{H}_{2} \mathrm{O}$ as used in the wood industry $(3 \%, 6 \%$ and $9 \% \mathrm{w} / \mathrm{w}$ ) were prepared and used to investigate their influence on the corrosion performance of AISI 316 and AISI 304 steels. The $\mathrm{Na}_{2} \mathrm{~B}_{4} \mathrm{O}_{7} \cdot 5 \mathrm{H}_{2} \mathrm{O}$ was obtained from ETI Mine Works General Management Company [21]. Data for the chemical specifications of the $\mathrm{Na}_{2} \mathrm{~B}_{4} \mathrm{O}_{7} \cdot 5 \mathrm{H}_{2} \mathrm{O}$ can be seen in Table 2 .

Table 2. Chemical specifications of $\mathrm{Na}_{2} \mathrm{~B}_{4} \mathrm{O}_{7} \cdot 5 \mathrm{H}_{2} \mathrm{O}$.

\begin{tabular}{ccc} 
Component & Unit & Content \\
\hline $\mathrm{B}_{2} \mathrm{O}_{3}$ & $\%$ & 47.76 min. \\
\hline $\mathrm{Na}_{2} \mathrm{O}$ & $\%$ & $21.25 \mathrm{~min}$. \\
\hline $\mathrm{SO}_{4}$ & $\mathrm{ppm}$ & 135 max. \\
\hline $\mathrm{Cl}$ & $\mathrm{ppm}$ & 70 max. \\
\hline $\mathrm{Fe}$ & $\mathrm{ppm}$ & 5 max. \\
\hline $\mathrm{Purity}$ & $\%$ & $99.90 \mathrm{~min}$. \\
\hline Insoluble in water & $\mathrm{ppm}$ & 150 max.
\end{tabular}

\subsection{Electrochemical methods}

Potentiodynamic polarisation and EIS measurements were carried out using the Gamry Instrument Potentiostat/Galvanostat/ZRA. The obtained data were analysed with the use of Gamry software. The experiment was performed in a three-electrode configuration. The AISI 316 and AISI 304 stainless steels were used as the working electrode, whereas an $\mathrm{Ag} / \mathrm{AgCl}$ electrode and a platinum mesh were employed as the reference electrode and the counter electrode, respectively [22]. The experimental setup is illustrated in Figure 1. Experiments were repeated at least seven times for both electrochemical methods and the closest result to the average was chosen and presented in the paper. All electrochemical experiments were performed under aerated condition at ordinary temperature. 


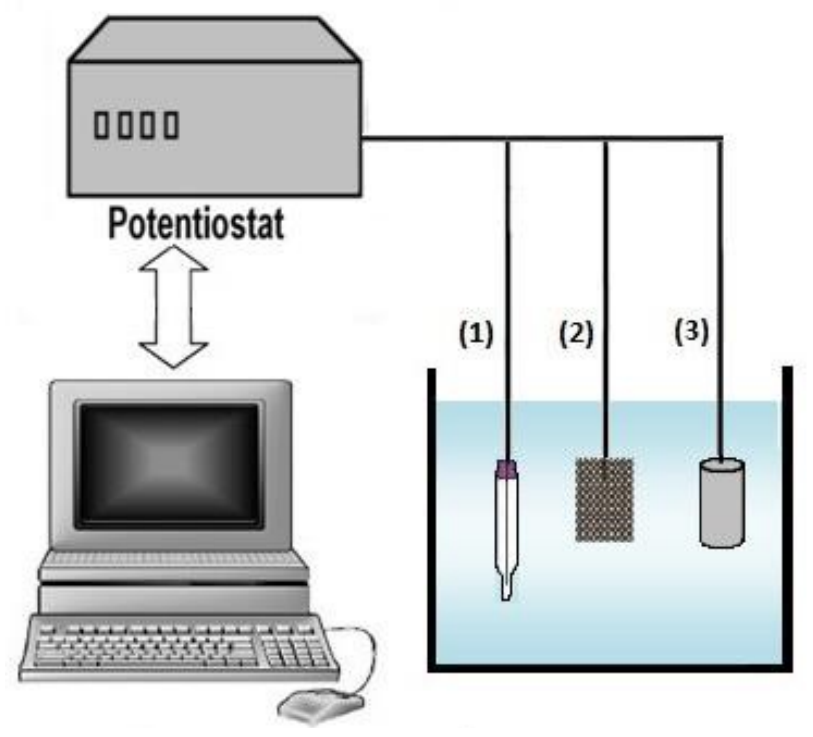

Figure 1. Experiment setup: (1) $\mathrm{Ag} / \mathrm{AgCl}$ electrode, (2) Pt mesh, (3) working electrode.

\subsubsection{Tafel polarisation method}

Polarisation curves were recorded at a constant sweep rate of $1 \mathrm{mV} / \mathrm{s}$ at -300 to $+300 \mathrm{mV}$ intervals with respect to the open circuit potential $\left(E_{\text {corr }}\right)$. Corrosion current density values $\left(I_{\text {corr }}\right)$ were calculated by using the Tafel extrapolation method and by taking an extrapolation interval of $\pm 250 \mathrm{mV}$ around the $E_{\text {corr }}$ value once it was stabilised [23].

\subsubsection{Electrochemical impedance spectroscopy}

Electrochemical impedance spectroscopy was performed using the Gamry Instrument Potentiostat/Galvanostat/ZRA and the EIS measurements were carried out at an open $E_{\text {corr }}$ by using an amplitude signal of $10 \mathrm{mV}$ in the frequency range of $100 \mathrm{kHz}-1 \mathrm{~Hz}$. In order to obtain more mechanistic information on the inhibition mechanism, an equivalent electrical circuit (Figure 2) was utilised to fit the experimental data. As a result, the resistance solution $\left(R_{\mathrm{s}}\right)$, charge transfer resistance $\left(R_{\mathrm{ct}}\right)$ and constant phase element $(\mathrm{CPE})$ $Q$ were determined. An electrical analysis was conducted with the use of the ZSimpWin 3.21 software. This software has the capability to measure the compatibility of the used circuit ( $\chi^{2}$ parameter) [24]. During the analysis, $\chi^{2}$ did not exceed $1 \times 10^{-4}$, attesting to a very high fit of the received impedance spectra to the proposed electrical equivalent circuit.

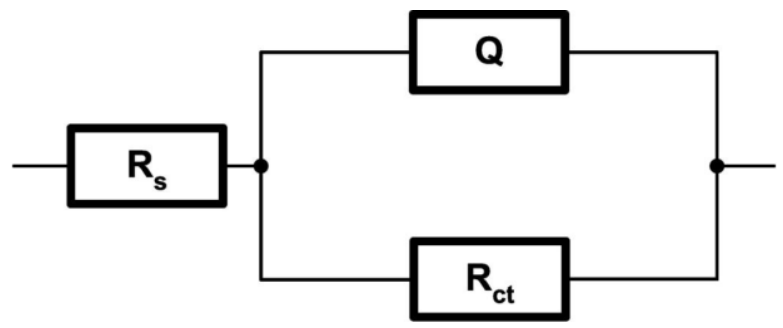

Figure 2. Model of an $R(Q R)$ electrical circuit. 


\section{Results and Discussion}

\subsection{Tafel extrapolation}

Figures 3 and 4 present the Tafel polarisation characteristics of AISI 316 and 304 stainless steel alloys in $3 \%, 6 \%$ and $9 \%$ concentrations of $\mathrm{Na}_{2} \mathrm{~B}_{4} \mathrm{O}_{7} \cdot 5 \mathrm{H}_{2} \mathrm{O}$ solution. It can be observed that the polarisation curves moved toward the lower current density region in the presence of the $\mathrm{Na}_{2} \mathrm{~B}_{4} \mathrm{O}_{7} \cdot 5 \mathrm{H}_{2} \mathrm{O}$ solution. For both study samples, compared with the $3 \%$ solution results, the cathodic branches of the polarisation curves recorded for each compound shifted explicitly to the direction of the current deduction, which implied that all concentrations of $\mathrm{Na}_{2} \mathrm{~B}_{4} \mathrm{O}_{7} \cdot 5 \mathrm{H}_{2} \mathrm{O}$ solution had an effect on the cathodic reaction of the corrosion process. Moreover, it can be seen in Table 3 that the values of corrosion potential moved more in the negative direction with the addition of each compound. Due to the negative shifts in the corrosion potentials and the noticeable decrease of the cathodic currents with the addition of compounds into the test solution, the three compounds under study can be considered as cathodic inhibitors (in this study, $3 \%$ of $\mathrm{Na}_{2} \mathrm{~B}_{4} \mathrm{O}_{7} \cdot 5 \mathrm{H}_{2} \mathrm{O}$ solution was used as a reference) $[25,26]$.

Table 3 demonstrates the Tafel parameters (TP), including the anodic Tafel slope $\left(\beta_{\mathrm{a}}\right)$, the cathodic Tafel slope $\left(\beta_{\mathrm{c}}\right)$, corrosion potential $\left(E_{\text {corr }}\right)$, and corrosion current densities $\left(I_{\text {corr }}\right)$.

It can be seen from Table 3 that the $I_{\text {corr }}$ values increase with the increase in the concentration of $\mathrm{Na}_{2} \mathrm{~B}_{4} \mathrm{O}_{7} \cdot 5 \mathrm{H}_{2} \mathrm{O}$ for both studied stainless steel alloys.

\subsection{Electrochemical impedance measurements}

The corrosion behaviour of AISI 316 and 304 stainless steel alloys in 3\%, 6\% and 9\% concentrations of $\mathrm{Na}_{2} \mathrm{~B}_{4} \mathrm{O}_{7} \cdot 5 \mathrm{H}_{2} \mathrm{O}$ solution was examined by electrochemical impedance spectroscopy (EIS). Figures 5 and 6 shows the impedance spectra in Nyquist format. For all the studied compounds, the impedance diagrams display one single capacitive loop represented by a slightly depressed semicircle. This capacitive loop indicates that the corrosion of the alloys in $3 \%, 6 \%$ and $9 \%$ concentrations of $\mathrm{Na}_{2} \mathrm{~B}_{4} \mathrm{O}_{7} \cdot 5 \mathrm{H}_{2} \mathrm{O}$ solution is mainly controlled by the charge transfer process and the formation of an adsorption layer on the metal surface [27]. All experimental spectra were fitted with an appropriate equivalent circuit (Figure 2) in order to find the parameters which described and were consistent with the experimental data. All obtained data from EIS are presented in Table 4. 


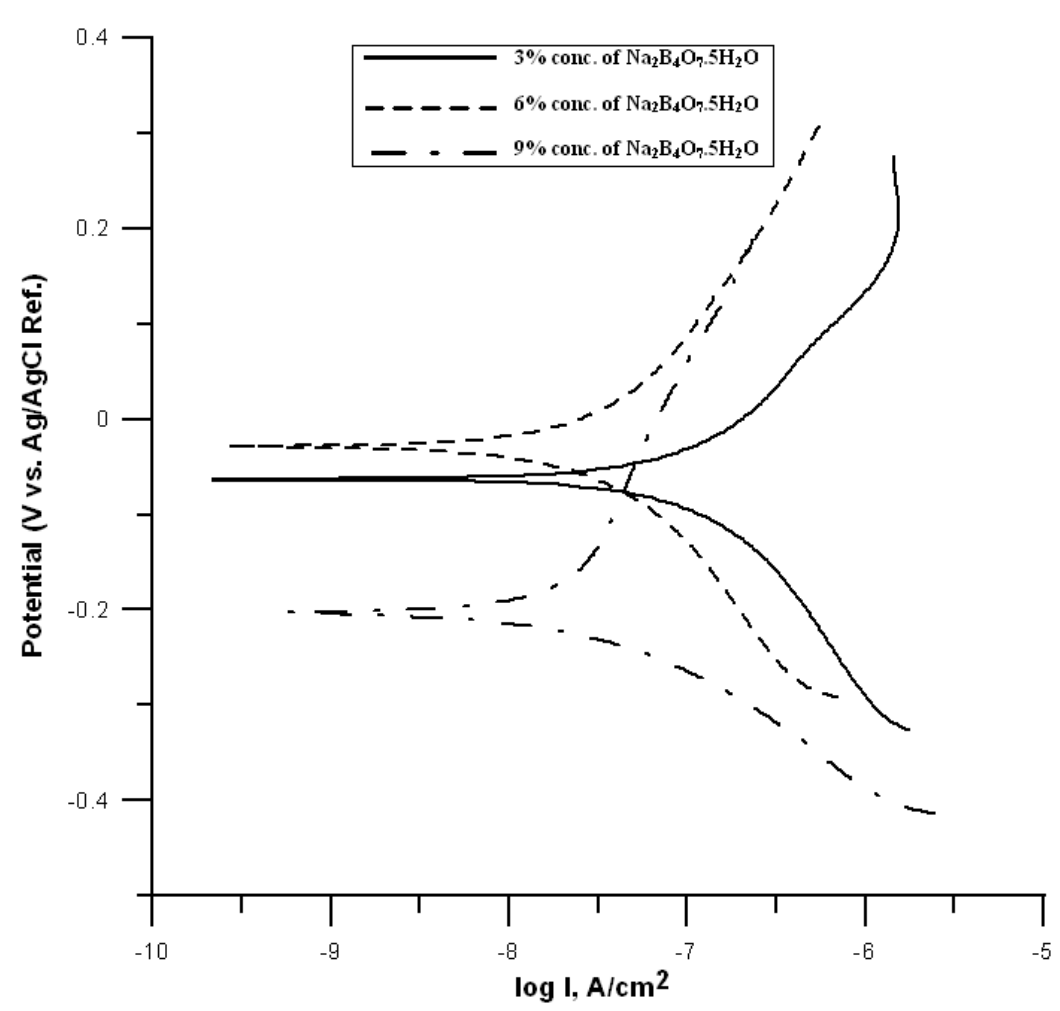

Fig. 3. The potentiodynamic polarisation curves of AISI 316 stainless steel alloy in $3 \%, 6 \%$ and $9 \%$ concentrations of $\mathrm{Na}_{2} \mathrm{~B}_{4} \mathrm{O}_{7} \cdot 5 \mathrm{H}_{2} \mathrm{O}$ solution.

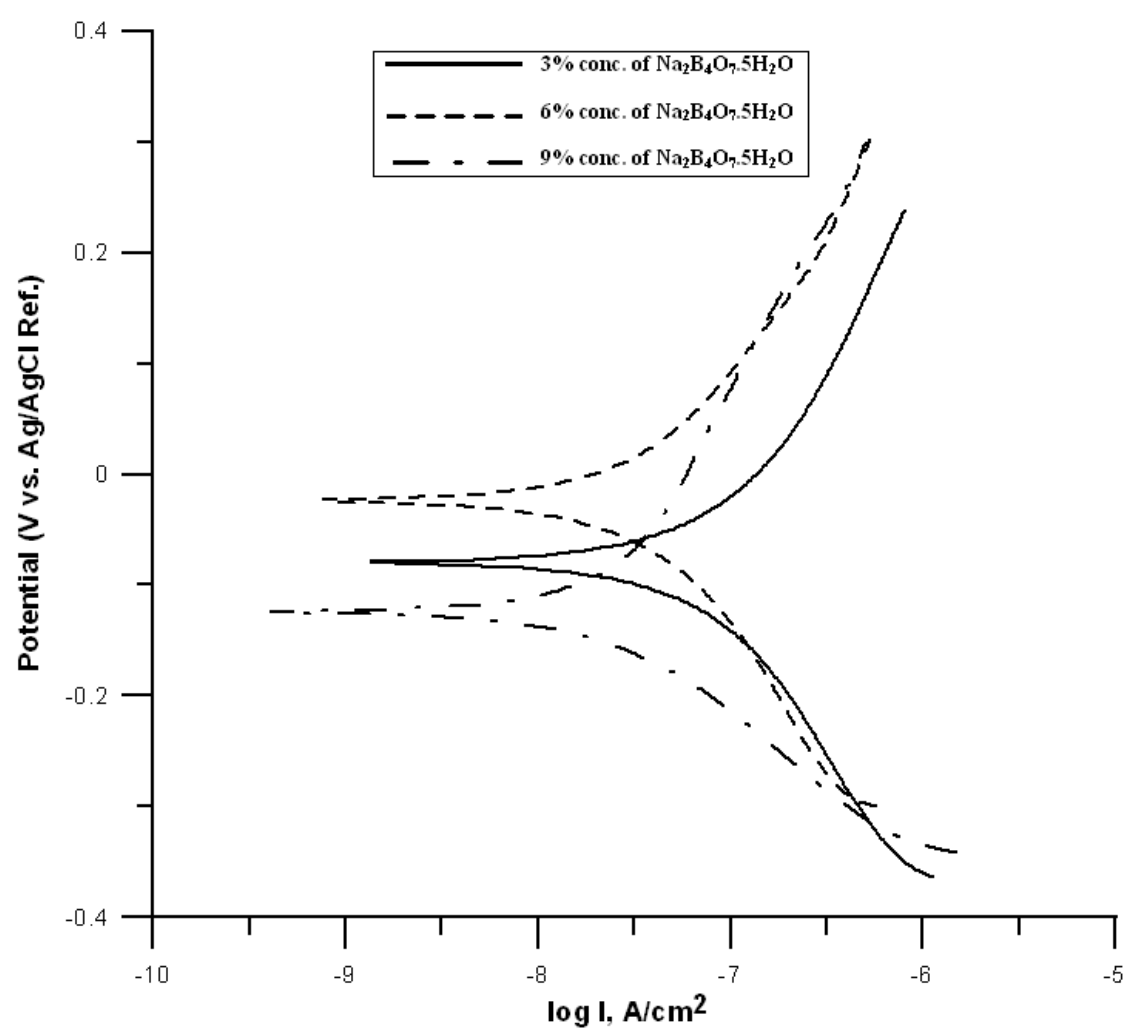

Figure 4. The potentiodynamic polarisation curves of AISI 304 stainless steel alloy in 3\%, 6\% and $9 \%$ concentrations of $\mathrm{Na}_{2} \mathrm{~B}_{4} \mathrm{O}_{7} \cdot 5 \mathrm{H}_{2} \mathrm{O}$ solution. 
Table 3. TP results of AISI 316 and 304 stainless steel alloys in different concentrations of $\mathrm{Na}_{2} \mathrm{~B}_{4} \mathrm{O}_{7} \cdot 5 \mathrm{H}_{2} \mathrm{O}$ solution.

\begin{tabular}{cccccc}
\hline Metal Type & Concentration & $\begin{array}{c}\boldsymbol{\beta}_{\mathbf{a}} \\
(\mathbf{m V} / \mathbf{D e c})\end{array}$ & $\begin{array}{c}\boldsymbol{\beta}_{\mathbf{c}} \\
(\mathbf{m V} / \mathbf{D e c})\end{array}$ & $\begin{array}{c}\boldsymbol{E}_{\text {corr }} \\
(\mathbf{m V})\end{array}$ & $\begin{array}{c}\boldsymbol{I}_{\text {corr }} \\
\left(\boldsymbol{\mu A} \mathbf{A} / \mathbf{c m}^{\mathbf{2}}\right)\end{array}$ \\
\hline \multirow{3}{*}{ AISI 316 } & $3 \%$ & 378 & 282 & -30 & 1.45 \\
\cline { 2 - 6 } & $6 \%$ & 326 & 265 & -63 & 0.90 \\
\hline \multirow{3}{*}{ AISI 304 } & $9 \%$ & 413 & 93 & -203 & 0.35 \\
\cline { 2 - 6 } & $3 \%$ & 376 & 428 & -80 & 2.12 \\
\cline { 2 - 6 } & $6 \%$ & 358 & 328 & -24 & 1.21 \\
\hline
\end{tabular}

It was necessary to use a constant phase element (CPE) instead of a double-layer capacity to account for the non-ideal behaviour. The CPE can be modelled as follows:

$$
Z_{\mathrm{CPE}}=\left[Q(j \omega)^{n}\right]^{-1}
$$

where $Z_{\mathrm{CPE}}$ is the impedance, $j$ the square root of $-1, \omega$ the frequency, $Q$ the capacitance, and $n$ is a measure of the non-ideality of the capacitor and has a value in the range of $0 \leq n \leq 1$ [28]. According to Eq. (2), the CPE element might be considered as a double-layer capacitor only when $n$ values remain close to 1 .

It is noticeable that the decrease in $Q$ values is associated with an increase in $n$ values [29]. The employment of $Q$ and $n$ parameters is justified in the event that changes are related to the surface heterogeneity [30]. It is assumed that water molecules present on a metal/solution interface possess a higher value of the relative dielectric constant [31]. When water molecules are replaced by inhibitor molecules, there is a decrease in the value

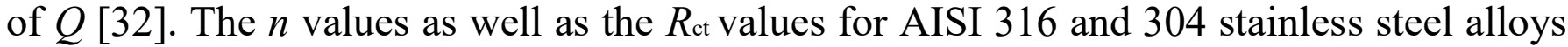
exposed to $3 \%, 6 \%$ and $9 \% \mathrm{Na}_{2} \mathrm{~B}_{4} \mathrm{O}_{7} \cdot 5 \mathrm{H}_{2} \mathrm{O}$ increased simultaneously with the increased concentrations of the solution.

From the electrical analysis of the impedance data for AISI 316 and 304 stainless steels in $3 \%, 6 \%$ and $9 \%$ concentrations of $\mathrm{Na}_{2} \mathrm{~B}_{4} \mathrm{O}_{7} \cdot 5 \mathrm{H}_{2} \mathrm{O}$ solution, the charge transfer resistance $\left(R_{\mathrm{ct}}\right)$ was obtained. It can be seen from Table 4 that the $R_{\mathrm{ct}}$ results increased in parallel with the concentration of $\mathrm{Na}_{2} \mathrm{~B}_{4} \mathrm{O}_{7} \cdot 5 \mathrm{H}_{2} \mathrm{O}$. Obtained results from the Tafel extrapolation and EIS analyses exhibited the same upward movement with the increase of the $\mathrm{Na}_{2} \mathrm{~B}_{4} \mathrm{O}_{7} \cdot 5 \mathrm{H}_{2} \mathrm{O}$ concentration. 


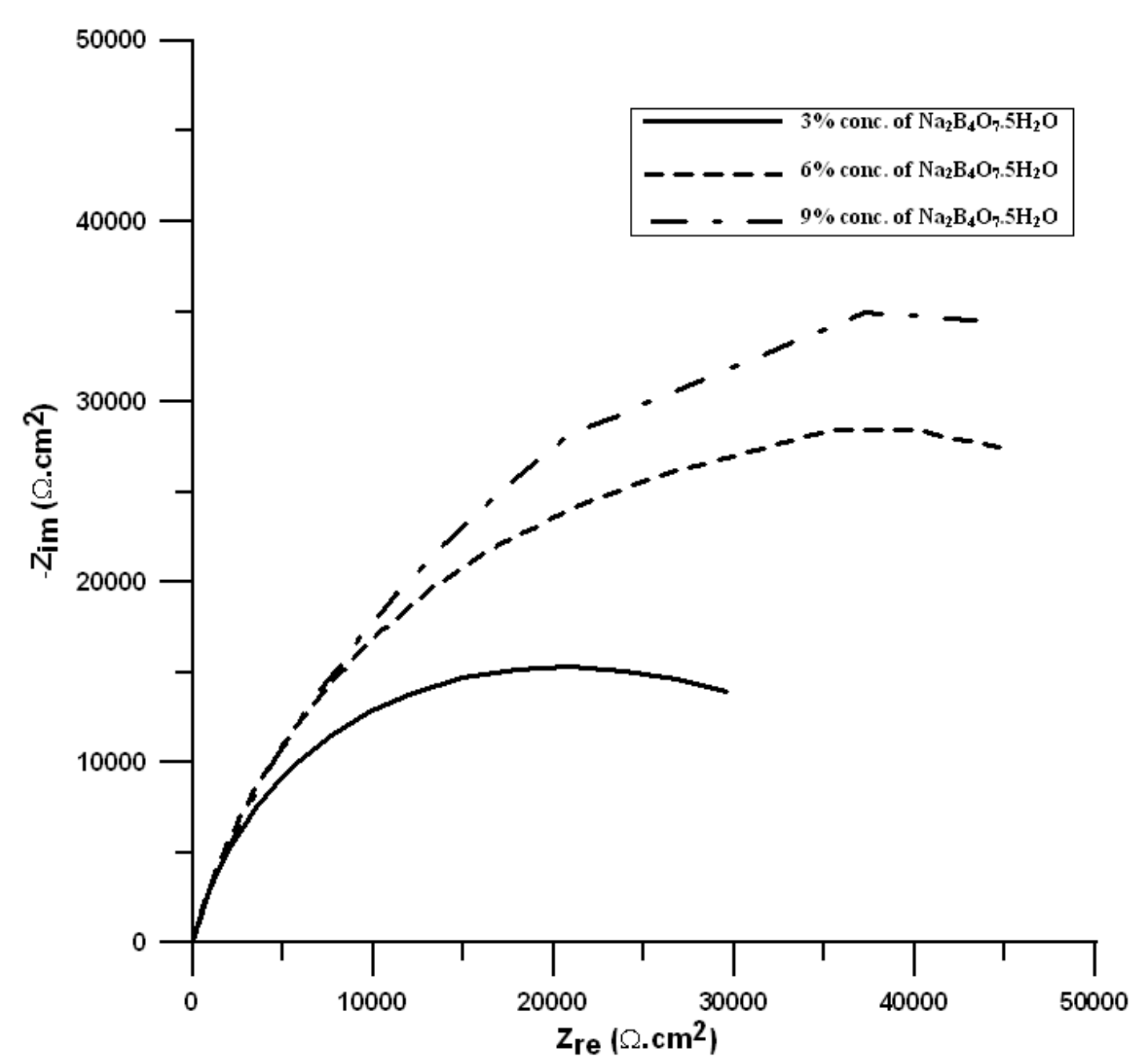

Figure 5. Impedance spectra of AISI 316 stainless steel alloy in 3\%, 6\% and 9\% concentrations of $\mathrm{Na}_{2} \mathrm{~B}_{4} \mathrm{O}_{7} \cdot 5 \mathrm{H}_{2} \mathrm{O}$ solution.

Table 4. Electrical parameters obtained by means of EIS analysis.

\begin{tabular}{|c|c|c|c|c|}
\hline Metal Type & Concentration & $\underset{(O h \mathrm{ct}}{\left.R_{\mathrm{cm}}\right)^{2}}$ & $\underset{\left(Q / S s^{n} \mathbf{c m}^{-2}\right)}{Q}$ & $n$ \\
\hline \multirow{3}{*}{ AISI 316} & $3 \%$ & 37400 & $7.22 \cdot 10^{-5}$ & 0.82 \\
\hline & $6 \%$ & 58350 & $5.94 \cdot 10^{-5}$ & 0.84 \\
\hline & $9 \%$ & 89100 & $5.57 \cdot 10^{-5}$ & 0.86 \\
\hline \multirow{3}{*}{ AISI 304} & $3 \%$ & 35400 & $7.71 \cdot 10^{-5}$ & 0.82 \\
\hline & $6 \%$ & 50400 & $6.79 \cdot 10^{-5}$ & 0.83 \\
\hline & $9 \%$ & 79800 & $5.08 \cdot 10^{-5}$ & 0.84 \\
\hline
\end{tabular}




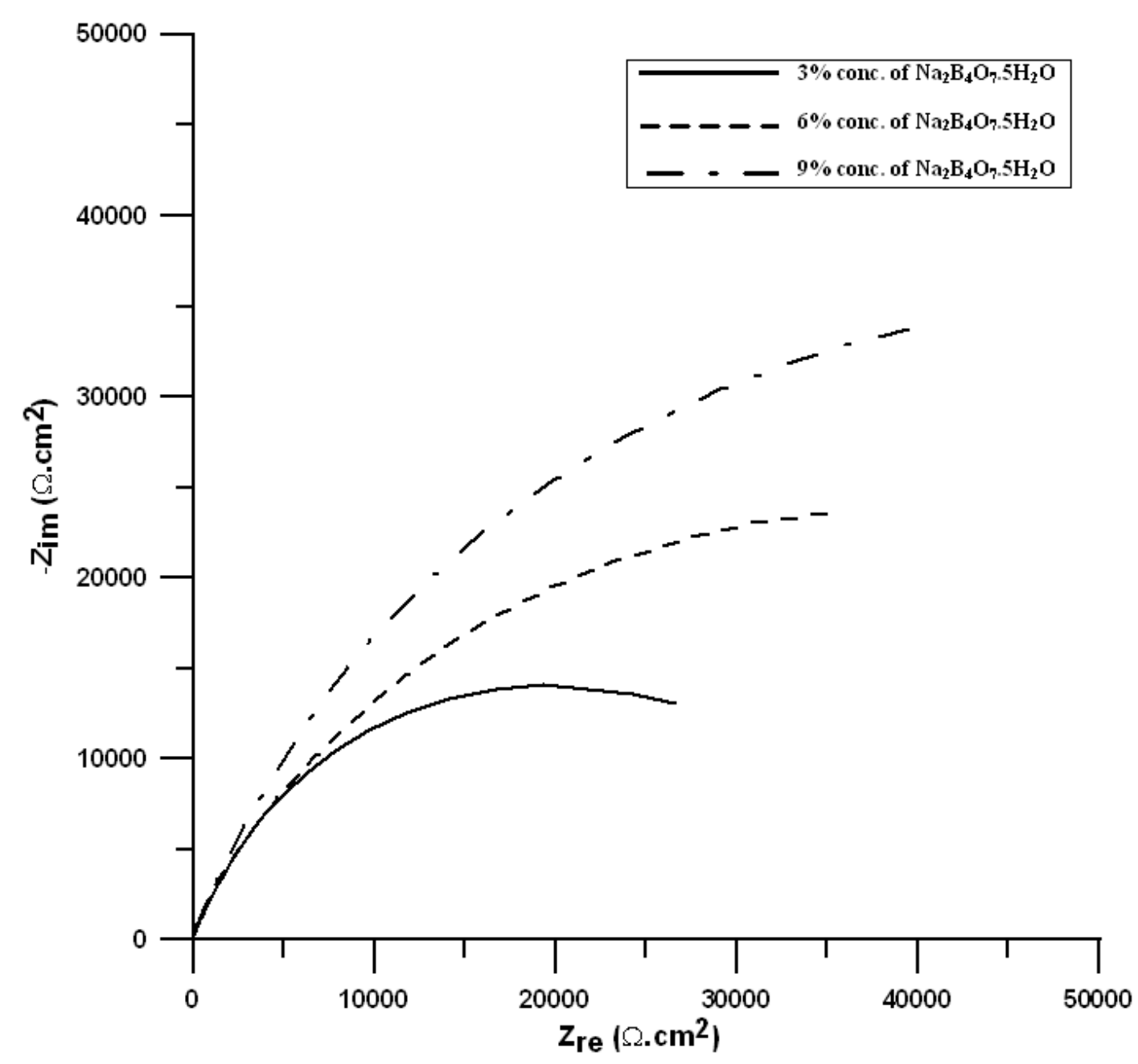

Fig. 6. Impedance spectra of AISI 304 stainless steel alloy in 3\%,6\% and 9\% concentrations of $\mathrm{Na}_{2} \mathrm{~B}_{4} \mathrm{O}_{7} \cdot 5 \mathrm{H}_{2} \mathrm{O}$ solution.

Figures 7 and 8 represent the Bode plots of AISI 316 and AISI 304 stainless steel alloys in $3 \%, 6 \%$ and $9 \%$ concentrations of $\mathrm{Na}_{2} \mathrm{~B}_{4} \mathrm{O}_{7} \cdot 5 \mathrm{H}_{2} \mathrm{O}$ solution. The phase angle values were appropriate for the $R_{\mathrm{ct}}$ changes. The phase angle for both investigated steel alloys increased with the increase in the concentration of $\mathrm{Na}_{2} \mathrm{~B}_{4} \mathrm{O}_{7} \cdot 5 \mathrm{H}_{2} \mathrm{O}$ in the corrosion cell and the phase angle value changes for both stainless steels were similar.

The phase angle value for the AISI 304 sample in $3 \% \mathrm{Na}_{2} \mathrm{~B}_{4} \mathrm{O}_{7} \cdot 5 \mathrm{H}_{2} \mathrm{O}$ solution was 58 , but increased to 66 and 74, respectively, with additions of $6 \%$ and $9 \% \mathrm{Na}_{2} \mathrm{~B}_{4} \mathrm{O}_{7} \cdot 5 \mathrm{H}_{2} \mathrm{O}$. The phase angle value for the AISI 316 sample in the $3 \% \mathrm{Na}_{2} \mathrm{~B}_{4} \mathrm{O}_{7} \cdot 5 \mathrm{H}_{2} \mathrm{O}$ was 61 , but increased to 68 and 77, respectively, with the additions of $6 \%$ and $9 \% \mathrm{Na}_{2} \mathrm{~B}_{4} \mathrm{O}_{7} \cdot 5 \mathrm{H}_{2} \mathrm{O}$. A similar tendency can also be seen in the Bode plots. The log values increased in parallel with the $\mathrm{Na}_{2} \mathrm{~B}_{4} \mathrm{O}_{7} \cdot 5 \mathrm{H}_{2} \mathrm{O}$ concentration. This can be attributed to the formation of an adsorption layer at the metal surface which acted as a barrier for the mass and the charge transfers. Thus, the similarity of these findings with the potentiodynamic polarisation results was demonstrated. 


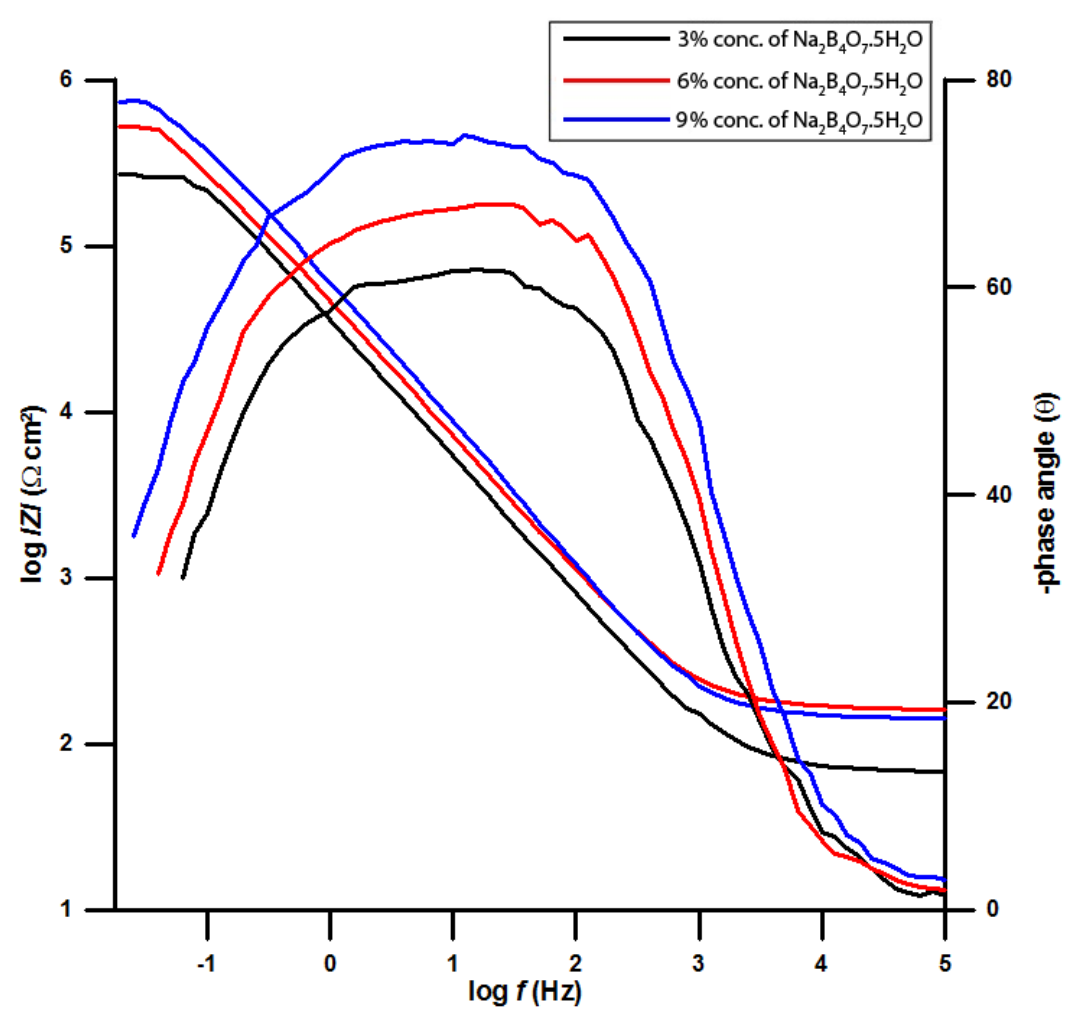

Figure 7. Bode plot for AISI 316 stainless steel alloy in 3\%,6\% and $9 \%$ concentrations of $\mathrm{Na}_{2} \mathrm{~B}_{4} \mathrm{O}_{7} \cdot 5 \mathrm{H}_{2} \mathrm{O}$ solution.

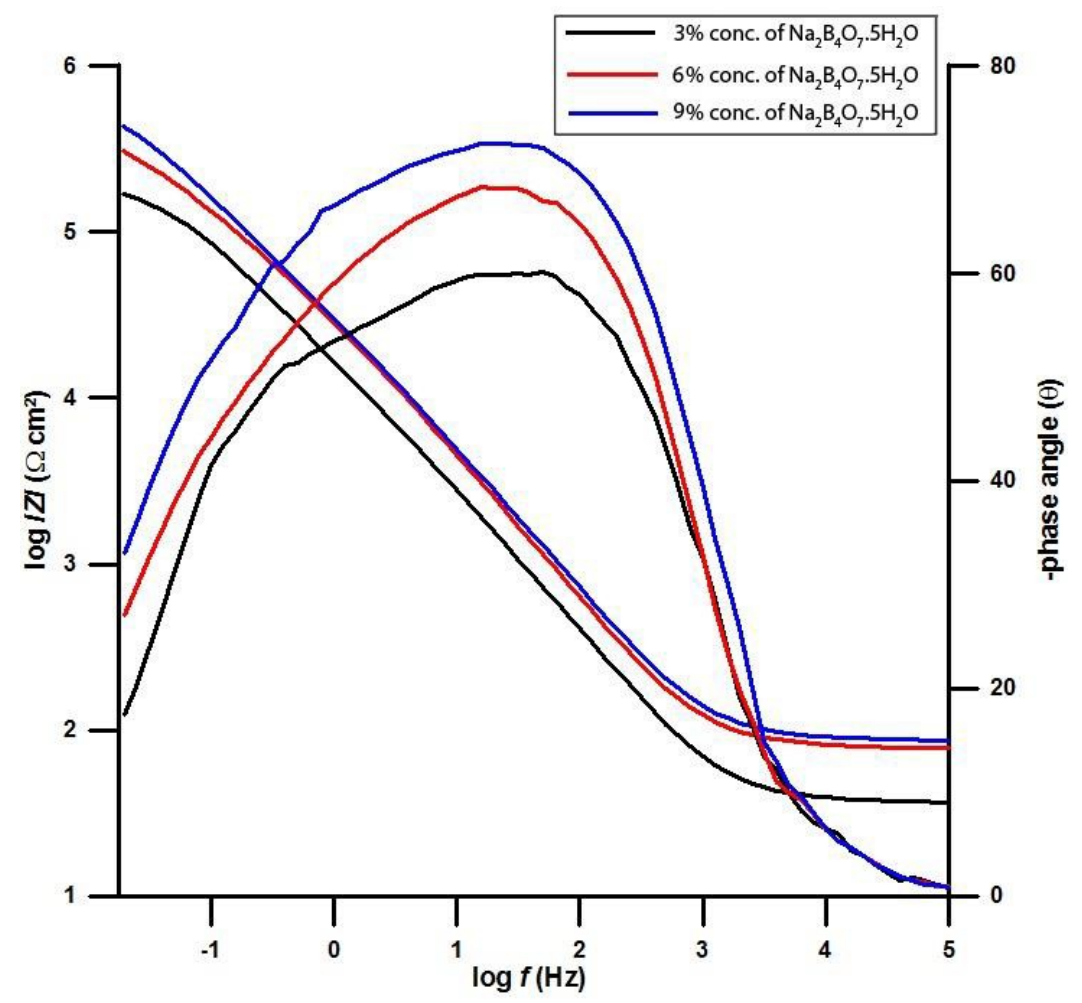

Figure 8. Bode plot for AISI 304 stainless steel alloy in 3\%, 6\% and $9 \%$ concentrations of $\mathrm{Na}_{2} \mathrm{~B}_{4} \mathrm{O}_{7} \cdot 5 \mathrm{H}_{2} \mathrm{O}$ solution 
The effect of the $\mathrm{Na}_{2} \mathrm{~B}_{4} \mathrm{O}_{7} \cdot 5 \mathrm{H}_{2} \mathrm{O}$ solution $(3 \%, 6 \%$ and $9 \%$ ) on the 316-type stainless steel was stronger than on the 304-type stainless steel. The 316-type alloy is an austenitic chromium-nickel stainless and heat-resisting steel. It displays superior corrosion resistance when exposed to many types of chemical corrodents such as seawater, brine solutions, etc., when compared to other chromium-nickel steels. Since the 316-type stainless steel alloy contains molybdenum, it has a greater resistance to chemical attack than the 304-type steel $[33,34]$.

\section{Conclusions}

1. The corrosion current density $\left(I_{\text {corr }}\right)$ results for AISI 316 and 304 stainless steel alloys were decreased with the increase in the $\mathrm{Na}_{2} \mathrm{~B}_{4} \mathrm{O}_{7} \cdot 5 \mathrm{H}_{2} \mathrm{O}$ concentration; however, the AISI 316 stainless steel exhibited better resistance than the 304-type stainless steel alloy. The AISI 304 contains more $\mathrm{Cr}(18.17 \%)$ and less Ni (8.07\%) compared to the AISI 316, with $16.29 \% \mathrm{Cr}$ and $10.10 \% \mathrm{Ni}$; thus, it is assumed that the higher resistance of the AISI 316 stainless steel was a result of the higher nickel content in the sample.

2. The corrosion behaviour of AISI 316 and 304 stainless steel alloys in 3\%, 6\% and 9\% concentrations of $\mathrm{Na}_{2} \mathrm{~B}_{4} \mathrm{O}_{7} \cdot 5 \mathrm{H}_{2} \mathrm{O}$ solution was examined via electrochemical techniques. The values of the obtained results were in good agreement with each other. Tafel extrapolation and electrochemical impedance revealed that the higher the concentration of the solution used, the lower the corrosion rate achieved.

3. Parameters such as $\beta_{a}$ and $\beta_{c}$ calculated from the Tafel plots proved that the $\mathrm{Na}_{2} \mathrm{~B}_{4} \mathrm{O}_{7} \cdot 5 \mathrm{H}_{2} \mathrm{O}$ solution acted as a cathodic-type inhibitor.

\section{Acknowledgements}

The financial support from The Republic of Turkey Ministry of Science, Industry and Technology (000653.STZ.2010.2) is gratefully acknowledged. We thank Divapan Integrated Wood Company, Duzce, Turkey, for their help.

\section{References}

1. D. Talbot and J. Talbot, Corrosion Science and Technology, CRC Press, Boca Raton, Florida, 1998.

2. T.H. Muster, A.E. Hughes, S.A. Furman, T. Harvey, N. Sherman, S. Hardin, P. Corrigan, D. Lau, F.H. Scholes, P.A. White, M. Glenn, J. Mardel, S.J. Garcia and J.M.C. Mol, Electrochim. Acta, 2009, 54, 3402.

3. B. Sanyal, Prog. Org. Coat., 1981, 9, 165.

4. N.A. Negm, N.G. Kandile, E.A. Badr and M.A. Mohammed, Corros. Sci., 2012, 65, 94.

5. C.B. Verma, M.A. Quraishi and A. Singh, J. Taiwan Inst. Chem. Eng., 2015, 49, 229.

6. A. Yıldırım and M. Çetin, Corros. Sci., 2008, 50, 155.

7. E.E. Oguzie, Mater. Chem. Phys., 2006, 99, 441. 
8. N.V. Tsirulnikova, Ya.V. Bolt, E.S. Dernovaya, B.N. Driker and T.S. Fetisova, Int. J. Corros. Scale Inhib., 2016, 5, no.1, 66. doi: 10.17675/2305-6894-2016-5-1-6

9. M.M. Antonijevic and M.B. Petrovic, Int. J. Electrochem. Sci., 2008, 3, 1. 10. I. Uygur, H. Gerengi, Y. Arslan and M. Kurtay, Mater. Res., 2015, 18, 569. 11. J.I. Bregman, Corrosion Inhibitors, Collier MacMillan Co, London, 1963.

12. O.K. Abiola, J.O.E. Otaigbe and O.J. Kio, Corros. Sci., 2009, 51, 1879.

13. O.K. Abiola and A.O. James, Corros. Sci., 2010, 52, 661.

14. M. Ozdemir and I. Kipcak, Miner. Eng., 2010, 23, 685.

15. E.A. Uwe, A.R. Boccaccini, S.G. Cook and C.R. Cheeseman, Ceram. Int., 2007, 33, 993.

16. K. Othmer, Encyclopedia of Chemical Technology, Wiley, New York, 1978.

17. Maas Graphite Company (http://www.maasgraphitecarbon.com/borax-pentahydrate).

18. A.J. Baker, Corrosion of metal in wood products, ASTM STP 691.

19. S. Zhang, T. Shibata and T. Haruna, Corrosion, 1998, 54, no. 6, 428.

20. L.H. Williams, APT Bulletin, 1996, 27, 46.

21. ETI Mine Works General Management Company (http://en.etimaden.gov.tr/).

22. H. Gerengi, K. Schaefer and H.I. Sahin, J. Ind. Eng. Chem., 2012, 18, 2204.

23. M.A. Lucio-Garcia, J.G. Gonzalez-Rodriguez, M. Casales, L. Martinez, J.G. ChaconNava, M.A. Neri-Flores and A. Martinez-Villafañe, Corros. Sci., 2009, 51, 2380.

24. S.J. Garcia, T.A. Markley, J.M.C. Mol and A.E. Hughes, Corros. Sci., 2013, 69, 346.

25. H. Keles, M. Keles, I. Dehri and O. Serindag, Colloids Surf. A, 2008, 320, 138.

26. S. Safak, B. Durana, A. Yurt and G. Turkoglu, Corros. Sci., 2012, 54, 251.

27. H. Gerengi, K. Darowicki, G. Bereket and P. Slepski, Corros. Sci., 2009, 51, 2573.

28. H. Gerengi, G. Bereket and M. Kurtay, J. Taiwan Inst. Chem. Eng., 2016, 58, 509.

29. H. Gerengi, Ind. Eng. Chem. Res., 2012, 51, 12835.

30. H. Gerengi and H.I. Sahin, Ind. Eng. Chem. Res., 2012, 51,780.

31. F.S. De Souza and A. Spinelli, Corros. Sci., 2009, 51, 642.

32. H. Gerengi, P. Slepski and G. Bereket, Mater. Corros., 2013, 64, 1024.

33. O.M. Alyousif and R. Nishimura, Corros. Sci., 2010, 52, 7.

34. Nema Enclosures Mfg. Corp. (http://www.nemaenclosures.com/materials/stainlesssteel-enclosures/316-stainless-steel.html). 